\title{
A comparison of designing practices in knitwear export units of Ludhiana and Tirupur
}

\author{
Lotika Gupta and Harminder Kaur Saini
}

Received: 14.06.2019; Revised: 05.11.2019; Accepted: 19.11.2019

See end of the paper for authors' affiliations Lotika Gupta Department of Apparel and Textile Science, Punjab Agricultural University, Ludhiana (Punjab) India

Email : lotikagupta1975@gmail.
ABSTRACT : The textile industry in India is the chief segment contributing largely to India's economic development. Knitwear exports hold a major share in India's total exports. The ever growing advancements in yarn, colour, materials and composition have given an advantage to the technique of knitting to such an extent that knitted fabrics have started taking place of woven fabrics. Knitted fabrics have become very popular because of their qualities such as stretch ability, wrinkle resistance, comfortable and snug fitting which makes it most suitable for casual and sportswear. Knitwear industry has very short product lifecycles, enormous product range, and quicker rate of demand and fashion change. Designing holds an important place in knitwear industry. Designing is directly linked with the generation of orders in foreign markets. Designers create garments and accessories making them functional as well as attractive, in accordance with the needs of the client. A number of designing practices are being followed in the knitwear export units of Ludhiana and Tirupur, which are major export hubs of India. The knitwear export units of Ludhiana found the services of in-house designers the best but knitwear units of Tirupur ranked the services of upcoming designers from fashion institutes best. As a source of inspiration, sketches received from foreign buyers was ranked first by knitwear export units of Ludhiana, while in Tirupur, fashion shows were ranked first. In Ludhiana Knit Pro 2.0 software was considered the best for designing of knitwears, while the knitwear export units of Tirupur, gave first rank to Knit Visualizer 1.2. It was noticed that maximum percentage of the knitwear units in Ludhiana and Tirupur, came out with a new style in the market within 3-6 months. The present study was undertaken to compare designing practices of knitwear export units of Ludhiana and Tirupur.

KEY WORDS: Knitwear, Export, Designing

- HOW TO CITE THIS PAPER : Gupta, Lotika and Saini, Harminder Kaur (2019). A comparison of designing practices in knitwear export units of Ludhiana and Tirupur. Asian J. Home Sci., 14 (2) : 415-420, DOI: 10.15740/HAS/AJHS/14.2/415-420. Copyright@ 2019: Hind Agri-Horticultural Society. 